\title{
Učitelia to určite zvládnu!
}

\author{
Jaroslav Pěnička
}

Univerzita Karlova, Pedagogická fakulta, Katedra preprimárnej a primárnej pedagogiky

Vyjadrujem svoj vel'ký obdiv všetkým učitel’om, ktorí v tomto období vynaložili enormné úsilie vzdelávat', vzdelávat' tak, aby bolo toto vzdelávanie čo najlepšie. Osobitne učitel'om, študentom, v kombinovanej forme štúdia, ktorých možno táto situácia, podla môjho názoru, zasiahla najviac, pretože od nich vyžadovala viac. $V$ tejto novej situácii neboli len študentmi, ale aj učitel'mi. Český štát kládol nároky, aby bolo vzdelávanie ekvivalentné normálnej situácii a aj samotná fakulta, na ktorej pôsobím, ich postavila pred úlohu byt' študentmi, ktorých vzdelávanie by malo byt' adekvátne bežnej situácii. Ale ako v poslednom čase často počúvame, situácia nie je normálna...

Môj príspevok môže miestami vyzniet' cynicky, ale ide len o kritické uvažovanie s cielom usporiadat' si vlastné myšlienky a poukázat' na vnímané limity súčasnej situácie, ako aj jej príležitosti, ktoré vznikli na jej základe. Kríza je v konečnom dôsledku vždy prospešná, pretože jedinca/systém núti k reakcii.

V príspevku budem reflektovat' svoje myšlienky a skúsenosti z uplynulých mesiacov ako absolventa odboru učitel'stvo pedagogiky a psychológie, začínajúceho vysokoškolského učitel'a a niekoho, kto sa venuje systému profesijného rozvoja a kariérneho rastu učitel'ov, s ciel'om apelovat' na systémovost' a na ciel. Príspevok delím po vzore tragédií do troch častí, úvod bude smerovat' ku kríze a tá dospeje ku katarzii.

\section{1 Úvod}

Zastávam presvedčenie, že to, čo študentov na pedagogických fakultách ${ }^{1}$ učíme, je potrebné. Vyštudovaný učitel' sa práve na základe vedeckých poznatkov dokáže erudovane rozhodovat' a volit' adekvátne formy a metódy výuky s ciel'om dosahovat' stanovený ciel'. Dokáže si svoje postupy obhájit' pred verejnou, ako aj odbornou komunitou. Tento fakt potvrdzujeme udelením titulu v učitel'ských odboroch za absolvovanie všetkých podmienok v štúdiu, ktoré sú akreditované štátom a v súhlase s legislatívnymi požiadavkami na učitela.

\footnotetext{
1 Rovnako ako aj na iných typoch školských inštitúcií https://doi.org/10.5817/PedOr2020-2-296
} 
Priznávam sa, do onoho momentu krízy som nezist'oval možnosti online vzdelávania. Rád verím v to, že pedagogické fakulty, ako aj katedry vyučujúce didaktiku, sú výkladnou skriňou možností vzdelávania. Bohužial', trendy slová, ako e-learning, som vždy skôr iba počúval, ako sa nimi zodpovedne zaoberal. Slovo e-learning zo svojich študentských čias by som zaradil do kategórie slov - interaktívna tabul'a - niečo vel'mi dobré a dá sa na tom robit' vel'a vecí, no necháme si to až na koniec, ked' nám ostane čas. Koniec koncov, aj tak sa od učitel'a nevyžaduje, aby vedel využívat' interaktívnu tabulu, alebo e-learningovo vzdelávat', lebo nevieme, či bude k tomu mat' na konkrétnej škole podmienky.

V čase písania príspevku sa Česká vláda ovieva názormi odborníkov, epidemiológov a poukazuje na to, že podla ich vedeckých odporúčaní postupujú. Respektíve, opatrne sa vyjadrujú k budúcemu stavu... „Možno..., uvidíme ako sa modely budú vyvíjat'." Ale ked' príde rad na školstvo? Jednoznačne - učitelia to zvládnu! Bude to možno výzva (doplňme nejaký náhodný fór/vtip, ktorý sa týka veku učitelov), ale oni to zvládnu. Prognózy? Dopady? Kvalita? Žiaci o nič neprídu. Normálne. Ekvivalentné. Učitelia to určite zvládnu!

Zredukovanie kurikula? - Je nutné zredukovat' obsah učiva a niektoré výchovy rovno vypustit'. A ja si v duchu kladiem tú klasickú otázku, ked' je možné niečo zredukovat', asi to nebolo dostatočne dôležité, pokial' tomu tak je, odôvodnená otázka, prečo to tam bolo? Pokial' to bolo dôležité, tak ako môže byt' súčasný stav adekvátny tomu, čo sme predtým požadovali? Prognózy? Dopady? Kvalita? Žiaci o nič neprídu. Normálne. Ekvivalentné. Učitelia to určite zvládnu!

\section{Kríza}

Považujem celkovo súčasnú situáciu za vel'mi nebezpečný precedens. Pokial' teraz povieme, že je niečo možné, tak už nebude cesty spät'. Od toho momentu môže byt' online vzdelávanie úplne adekvátne vzdelávaniu prezenčnému. Ved', prečo by niekto chodil do školy, ak je možné to všetko zvládnut' online. Situáciu, v ktorej po skončení krízového stavu si povieme, že to nebude možné, považujem za bizarnú. Zrazu bude znova nutná prezenčná účast' na seminároch. Tol'kokrát som do krízy z médií počul, ako na nemenovanej škole (pre)dávali študentom tituly, pričom absolventi ani len nechodili do školy! Teraz sme sa ocitli v situácií, že je online vzdelávanie ekvivalentné tomu prezenčnému. 
Úprimne, mám problém s tým, že sa majú študenti vzdelávat’online, ked' toto nie je forma štúdia, na ktorú sa prihlásili. Ja si nepamätám, že prístup k PC a internetu bol nutný k štúdiu na pedagogickej fakulte a rovnako si nepamätám, že to bolo od študentov vyžadované v rámci prijímacích skúšok. Ked' učím, častokrát si hovorím, ako by bolo super, keby mal každý v triede počítač a mohol si niečo dohl'adat', bohužial', to som od študentov nikdy nemohol vyžadovat' a ani vybavenie učební to nikdy plne neumožňovalo. Počas normálneho semestra úlohy typu - naskenovat' QR kód a zapísat' sa tak na prezenčnú listinu? Nepredstavitel'né, to len zas na nich niečo vymýšl'am! So zármutkom nahrávam na YouTube video, ako sa prihlásit' na konzultačné hodiny v Doodle, a je mi clivo, pokial' mi študenti píšu, že je to stále zložité.

Pamätám si, ako nám bolo pred rokom oznámené, že nemôžeme používat' iné produkty ako tie, ktoré nám poskytuje Univerzita z dôvodu ochrany osobných údajov študentov. Príchodom krízy sa celé GDPR akoby stratilo. Študentov a zamestnancov nútime inštalovat' si do vlastných zariadení ${ }^{2}$ rôzne programy s cielom, aby sme sa mohli/skúšali spojit' online. Cítim povinnost' naučit' svojich študentov to, čo považujem za potrebné a správne, rovnako ako cítim aj bezmocnost', ked' viem, ako by som im mohol pomôct', ale nemôžem, pretože je to $\mathrm{v}$ rozpore $\mathrm{s}$ tým, čo mám predpísané. Rozumiem, že po bitke je každý generál, pokial' by som mohol používat' alternatívne nástroje, možno by som bol viac pripravený na súčasnú situáciu. Možno by som tomu venoval viac, zistoval, skúšal, skúmal. Skype, Zoom, G-suite, alebo nový Microsoft teams všetko to boli veci do krízy zakázané, pretože dáta neboli na univerzitných serveroch a teda bol možný únik osobných informácií.

V konečnom dôsledku som sklamaný a považujem čas, ktorý som venoval zistovaním funkcionalít v Moodle ${ }^{3}$ za pomerne stratený, pretože moja nakumulovaná vedomost' slúži iba k tomu, aby som dokázal administrovat’ svoj predmet. Bez akéhokolvek presahu, pretože moji študenti, budúci učitelia, nebudú mat' Moodle na svojej škole a je teda zbytočné ich učit' ho používat'.

Vidím farebné metodiky, ako majú učitelia vyučovat', rôzne, praktické kurzy a programy, ale nevidím argumenty podložené dostatočným výskumom, ktoré dokazujú, že to je tak. Pokial' by som také texty dostal od svojich

2 Pokial' si nechcem do súkromného počítača nainštalovat’ nejakú aplikáciu, neostáva mi nič iné, ako íst' na fakultu. No v prípade študenta je to jeho jediná možnost', ked'že zázemie, ktoré poskytuje školská inštitúcia normálne, je neprístupné.

3 Learning management system platforma využívaná na Univerzite Karlovej. 
študentov, tak by som im napísal „,a toto máte odkial?", „, na základe čoho toto tvrdíte?“. Teraz, v čase korony, to jednoducho vieme. Ved' je to to isté, len je to online. Odhliadnuc od úplne inej formy, modifikovaných metód. Na online vzdelávanie neboli učitelia systematicky a cielavedome pripravovaní a, v konečnom dôsledku, kvalifikovaní. Ked' počúvame o tom, že učitelom chýba kontakt so žiakmi - tak je to preto, lebo ich celý systém vždy učil pozorovat', ako sa počas hodiny správajú a pracujú, evaluovat' ich činnost' a pružne reagovat' na reakcie žiakov. Je to podobné tomu, ako by sme učitel'ovi občianskej náuky dali učit' ešte aj telesnú výchovu - ved' to zvládne, a navyše sa mu doplní úväzok. Je to ako dávat' rozcvičku, všetci sme videli, ako taká rozcvička vyzerá, dokážeme ju napodobnit', ale neznamená to, že vieme čo v skutočnosti robíme.

V súčasnosti vidím vela videí rôznych agentúr, ich webinárov o tom, ako vzdelávat' online $\mathrm{v}$ takom či onakom programe. Pričom situácia s online kurzmi môže byt' podobná, ako na Slovensku v začiatkoch kariérneho systému. Ked' vznikalo viacero kurzov, ktoré bez nutnosti akreditácie (Galas \& Rehúš, 2016, s. 4) poskytovali učitel'om možnost' diskutabilných kreditov za kurzy háčkovania. Nechcem spochybnit' dobrý úmysel s cielom pomôct', ale desí ma až príliš úzka hranica medzi garantovaným (akreditovaným) programom a YouTube videom. Mám obavu zo súkromného sektora, ktorý môže byt' poháňaný biznis myslením, robit' si PR, maximalizovat' zisk, nebát' sa bankrotu, riskovat'.

Naštastie z toho „agentúrneho“ online vzdelávania žiaden oficiálny certifikát nie je. Čo cynicky považujem za celkom lacné riešenie situácie, ked' neoficiálne zvýšime kvalifikáciu všetkým učitel'om a naučíme ich využívat' nové technológie. Popri tom im tento proces zvýšenia kvalifikácie žiadnym spôsobom neoceníme a v konečnom dôsledku ani nezaplatíme, pretože sa v konečnom dôsledku nič nezmení, bude to stále ten istý učitel', z pohl'adu českého štátu nebude o nič lepší, lebo (okrem ročného automatu) formálne ostane na rovnakej úrovni ${ }^{4}$.

4 Z pohladu učitel’a celkom bežná realita, ale z biznis mentality toto správanie nedáva žiaden zmysel, pretože vstupná investícia presahuje potencionálny zisk. Pre biznis myslenie je omnoho prirodzenejšie, 0. Urobit' focus (napríklad na FB), čo učitelom chýba. 1. Vytvorit' počítačový program (upravit' nejaký open source). 2. Pripravit' kurz (pre učitelov zadarmo, s trendy nadpisom a vágnym obsahom). 3. Predat' program školám (najlepšie zo šablon alebo OPVVV). Jednoducho, predstava riadit' školu (štát) ako firmu nemôže fungovat', pretože stoja na rozličných ideologických základoch. 
Dost'! Je to nesystémové a nemá to ciel'! Prognózy? Dopady? Kvalita? Žiaci o nič neprídu. Normálne. Ekvivalentné. Učitelia to určite zvládnu! ${ }^{5}$

\section{Katarzia}

Súhlasiac s Freudovým povzdychom nad situáciou psychoanalytika, byt' učitel'om je jedno z "impossible" professions (Freud, 1937, s. 401). Dostát' všetkým (vnútorným aj vonkajším) požiadavkám a očakávaniam nie je lahké ani v čase, ktorý považujeme za normálny. Situáciu možno často krát komplikuje, že nevieme, čo vlastne od učitel'ov chceme. „Možno..., uvidíme, ako sa modely ${ }^{6}$ budú vyvíjat'."

Korona kríza ukázala, že v prípade postavenia školstva do priorít, sú všetci systémoví aktéri (decízna, akademická, profesijná sféra (Spilková \& Tomková, 2010, s. 22-38), schopní a ochotní spolupracovat' s cielom poskytnút' maximum, čo je v daných podmienkach možné. Definovat' ciel', na základe vedeckých poznatkov, zvolit' formy a metódy k jeho dosiahnutiu.

Súčasný stav potvrdzuje (Pěnička, 2019), že najsilnejšia motivácia učitel’ov k vzdelávaniu je tá, že sa prostredníctvom neho stávajú lepšími učitel'mi. Od kurzov d'alšieho vzdelávania očakávajú, že im pomôže a bude mat' pozitívny vplyv na ich vyučovanie. Pokial' sú učitel'om ponúknuté možnosti ${ }^{7}$ pre ich d’alšie vzdelávanie, tak sú ochotní sa prostredníctvom nich d’alej vzdelávat'. Tento náhl'ad vyžaduje, aby učitelia mali podmienky pre d’alšie vzdelávanie, aby poskytované formy d'alšieho vzdelávania boli funkčnẽ.

Nemôžeme sa spoliehat', čakat' na krízu, ktorá rozčerí stojaté vody v školstve. Pedagogika nie je hurá veda, nie je náhodné vzdelávanie bez stanovenia jasného ciel'a. Úlohou štátu je potvrdit', že školstvo je prioritná oblast' (Programové prohlášení vlády České republiky, 2018, s. 14), prihliadat' na názor učitelov a odborníkov a napríklad formou profesijných štandardov povedat', kto je učitel' a čo od neho očakávame. Vytvárat' podmienky pre učitel'ov, aby mohli svoju prácu vykonávat' najlepšie ako vedia, umožnit' učitelom, ktorí sa chcú d'alej vzdelávat', aby sa vzdelávat' mohli. Hlavne ale garantovat' kvalitu systému. Určit' ciel'. Nespoliehat' sa, že Učitelia to určite zvládnu!

\footnotetext{
5 Ale čo? Prekonat' krízu? Iba to je ciel??

6 PISA, TIMES, ČSI, výsledky maturít.

7 Také, ktoré učitelia sami považujú za funkčné a zmysluplné.
} 


\section{Literatura}

Freud, S. (1937). Analysis terminable and interminable, Standard Edition, vol. 23. London: Hogarth.

Galáš, P., \& Rehúš, M. (2016). Bez kreditov neodídem. Bratislava: Inštitút vzdelávacej politiky, Ministerstvo školstva, vedy, výskumu a športu SR. Dostupné z https://www.minedu.sk/ data/att/9665.pdf

Pěnička, J. (2019). Spoločné znaky medzi diskurzom učitel'ov o profesijnom rozvoji a kariérnom raste v Čechách a na Slovensku. Slavonic Pedagogical Studies Journal, 8(2), 322-330.

Programové prohlášení vlády České republiky. (2018). Dostupné z https://www.vlada.cz/assets/ jednani-vlady/programove-prohlaseni/Programove-prohlaseni-vlady-cerven-2018.pdf

Spilková, V., \& Tomková, A. (2010). Kvalita učitele a profesní standard. Praha: Univerzita.

\section{Autor}

Mgr. Jaroslav Pěnička, Univerzita Karlova, Pedaogická fakulta, Katedra primární pedagogiky, Magdalény Rettigové 4, 11639 Praha 1, Česká republika, e-mail: jaroslavpenicka@gmail.com 